\title{
Entrepreneurial women's cognitive ambidexterity: Career and cultural influences
}

\author{
M.J. de Villiers Scheepers*, C. Boshoff and M. Oostenbrink \\ Stellenbosch University, Private Bag X1, Matieland, 7602
}

*Also from the University of the Sunshine Coast, Australia

To whom all correspondence should be addressed: mscheepe@usc.edu.au

\begin{abstract}
The purpose of this study was to examine how women's career stage and Ubuntu (collectivist) values relate to their cognitive ambidexterity when pursuing entrepreneurial initiatives in multicultural South Africa. In this study individual cognitive ambidexterity was operationalised as using effectual and causal logic. More than three hundred businesswomen from diverse backgrounds were surveyed. The results revealed that career stage, self-efficacy and Ubuntu collectivism are important in women's ambidexterity. Mature, efficacious women in their late career stage draw on their diverse networks and use effectual affordable loss, flexibility and causation when pursuing entrepreneurial initiatives. In contrast, younger, early-career women are more likely to use pre-commitment to ensure support from stakeholders. Women with Ubuntu values use their relationship skills to draw on resources from their networks and use ambidexterity (effectual and causal logic) in their entrepreneurial endeavours.
\end{abstract}

The findings suggest that entrepreneurial women who develop their cognitive ambidexterity and draw on both effectual and causal approaches when initiating entrepreneurial initiatives are more likely to experience successful outcomes. These mental approaches can be developed by means of awareness, training and mentoring. This study extends the literature on women's entrepreneurial decision-making in a culturally diverse society, demonstrating the influence of cultural values and career stage on effectual and causal logic.

\section{Introduction}

Multi-tasking, described as the ability to switch between tasks or to handle multiple tasks simultaneously (Pashler, 2000), is embedded in today's demanding workplace in pursuit of efficiency, while simultaneously requiring rapid innovation (Appelbaum, Marchionni \& Fernandez, 2008). Popular books and media reports suggest women are better multi-taskers than are men (Pease \& Pease, 2003). While psychologists debate the issue (Mäntylä, 2013; Stoet, O'Connor, Conner \& Laws, 2013), many women view multi-tasking as part of their feminine workplace identity (Priola, 2004). Multi-tasking is a mental reality for women involved in entrepreneurial activities because these activities require cognitive ambidexterity. This type of ambidexterity entails balancing operational efficiency with innovation in an entrepreneurial project (Turner, Swart \& Maylor, 2013; Volery, Mueller \& Von Siemens, 2015). Evidence shows that career stage and cultural values, such as collectivism, strongly influence women's entrepreneurial behaviour (Braches \& Elliot, 2016; Terrell \& Troilo, 2010; Yousafzai, Saeed \& Muffatto, 2015), yet many questions remain unanswered (Brush, de Bruin \& Welter, 2009). For instance, how do heterogeneous groups of women use cognitive ambidexterity when pursuing entrepreneurial initiatives (Hughes \& Jennings, 2012; Hughes, Jennings, Bursh, Carter \& Welter, 2012)?

Recognising the influence of career and sociocultural contexts on cognitive ambidexterity emphasises the personal resources women draw on to produce novel outcomes. Some researchers argue that the paradoxical activities of searching for novel applications and simultaneously executing efficient routines create psychological tension (Raisch, Birkinshaw, Probst \& Tushman, 2009). Bock (2004), however, found that Dutch farmwomen are adept at multi-tasking when pursuing entrepreneurial activities and experience business development as financially challenging and emotionally rewarding. Volery et al. (2015) inductively identified certain behavioural patterns and competencies that facilitates entrepreneurial ambidexterity, although the theoretical underpinning in this area remains elusive and their study is silent on the experience of women as a heterogeneous group.

Against this background, this study examined the cognitive ambidexterity that South African women of diverse cultural backgrounds use in entrepreneurial initiatives, focusing on their career development and cultural values. This study extends the literature on women's entrepreneurial decisionmaking in a culturally diverse society in which some ethnic groups exhibit a form of collectivism as a cultural value (Adams, Van de Vijver, de Bruin \& Torres, 2014; Urban, 2006). It moves beyond 'standard business and personal profile' variables (Marlow, Henry \& Carter, 2009: 145) to provide insight into the cognitive processes women use to make entrepreneurial decisions (Mitchell, Mitchell \& Mitchell, 2009). Entrepreneurial behaviour is discussed in the context of both independent entrepreneurship and entrepreneurial activity in organisations. Women's entrepreneurial activity in South Africa represents a significant part of the economy: women make up $45 \%$ of 
people employed and rates of self-employment have grown in recent years (Simo Kenge, 2016). The authors adopt a form of 'strategic essentialism' (Spivak, 1987) in order to highlight the diversity of entrepreneurial women's experience and provide a voice for this group (Wu, 2013).

Using the lens of effectuation, an emerging theory in entrepreneurship, this study augments the conversation on individual ambidexterity. While effectual logics have been studied in expert entrepreneurs and novice managers (Dew, Read, Sarasvathy \& Wiltbank, 2009; Sarasvathy, 2001), in a corporate context (Brettel, Mauer, Engelen \& Kupper, 2011), and in home-based businesses (Daniel, Di Domenico \& Sharma, 2014), the ambidexterity of women seems to be overlooked. This study's thesis is that mature women who embrace Ubuntu values, balance effectual and causal logic, thus displaying ambidexterity when pursuing entrepreneurial initiatives. The study contributes to the literature in three ways. First, effectuation is linked to women's individual cognitive ambidexterity, providing a theoretical basis for ambidexterity in entrepreneurial initiatives. Second, it improves our understanding of the influence of career stage on women's cognitive ambidexterity. Third, the influence of a collectivist cultural orientation on ambidexterity is considered in the South African context.

This paper reviews the literature on ambidexterity as an individual-level construct, links it with effectuation theory and then argues how women's career stage, self-efficacy, cultural values and relationship skills are related to ambidexterity decision-making logics. Hypotheses were tested and the findings of this study are compared to the literature on women's entrepreneurship. In the final instance future research opportunities are highlighted.

\section{Entrepreneurial cognitive ambidexterity}

Entrepreneurial cognitive ambidexterity refers to the ability to pursue both innovation and efficiency perspectives, which requires entrepreneurs to switch between dichotomous mindsets while innovating (Bledow, Frese, Anderson, Erez \& Farr, 2009). Similar to organisational ambidexterity, this involves exploitation activities such as efficiency, choice and execution, as well as exploration activities such as experimentation, flexibility and innovation (Boumgarden, Nickerson \& Zenger, 2012; March, 1991). Volery et al. (2015) found that entrepreneurs do not associate ambidexterity with the tension discussed in the literature (Gupta, Smith \& Shalley, 2006); rather, they frequently switch between exploration and exploitation. Entrepreneurial women's career and cultural values affect how they balance these contradictory, yet interrelated, mind-sets (Bock, 2004). This study extends Volery et al.'s (2015) work by addressing the limited theorisation and practical implications at the individual level (Turner et al., 2013) by drawing on effectuation. This emergent theory provides principles for individual action and deconstructs action dimensions of exploration and exploration (see Table 1).

Effectuation, akin to exploration, refers to decision-making heuristics to navigate uncertainty when working on novel projects, and involves experimentation, risk-taking, discovery and flexibility (Chandler, De Tienne, McKelvie \& Mumford, 2011; Dew et al., 2009). Exploitation decisions, in contrast, are related to the rational, predictive approach, termed causation that emphasises efficiency, stability, prediction and execution (Sarasvathy, 2008; Wiltbank, Read, Dew \& Sarasvathy, 2009). For business women's exploration, effectual logic implies that they start by actively assessing their resources at hand, such as their personal, cultural and network capital (Brettel et al., 2011; Daniel et al., 2014). They actively shape their environment and broaden their knowledge base as they learn by experimenting and using new technologies or processes. While experimenting, they receive support from self-selected stakeholders who pre-commit and shape the initiative, simultaneously limiting downside losses by not risking more than they are prepared to lose (Wiltbank et al., 2006). In this evolutionary process, new knowledge and partnerships are forged and contingencies are viewed as learning opportunities (Chandler et al., 2001). Patterson and Mavin (2009) illustrate that mature women gain control over their future by means entrepreneurial behaviour and use their networks as resources.

Exploitation decisions start with goal setting and planning to acquire resources, and are focused on optimising organisational processes. These entrepreneurs forecast using scenarios and analysing existing data, leveraging their knowledge to evaluate decisions based on risk-adjusted returns and short-term results. This predictive approach creates reliability by either avoiding harmful contingencies or developing contingency plans. Utility maximisation is sought by applying current competencies and technologies. Those outside an organisation are seen as competitors and strategies are executed to maintain a defendable competitive position (Dew et al., 2009). 
Table 1: Relating effectuation to exploration and causation to exploitation as ambidextrous strategies

\begin{tabular}{|c|c|c|c|c|c|}
\hline Dimensions & Effectuation & Exploration & Causation & Exploitation & References \\
\hline Starting point & $\begin{array}{l}\text { Search for new } \\
\text { resources based on } \\
\text { existing, intangible } \\
\text { resources at hand } \\
\text { (e.g. human and } \\
\text { social capital) } \\
\end{array}$ & $\begin{array}{l}\text { Search for new } \\
\text { resources, organisational } \\
\text { norms, routines, } \\
\text { structures and systems }\end{array}$ & $\begin{array}{l}\text { Start with goal } \\
\text { setting, environmental } \\
\text { scanning; planning to } \\
\text { secure resources }\end{array}$ & $\begin{array}{l}\text { Optimise and } \\
\text { stabilise } \\
\text { organisational } \\
\text { routines, structures } \\
\text { and systems }\end{array}$ & $\begin{array}{l}\text { Levinthal \& } \\
\text { March, (1993); } \\
\text { Smith \& } \\
\text { Tushman (2005) }\end{array}$ \\
\hline Worldview & $\begin{array}{l}\text { Control: future } \\
\text { environment depends } \\
\text { on using existing } \\
\text { knowledge through } \\
\text { personal action }\end{array}$ & $\begin{array}{l}\text { Take action to broaden } \\
\text { existing knowledge } \\
\text { base; creation or } \\
\text { acquisition of new } \\
\text { knowledge }\end{array}$ & $\begin{array}{l}\text { Predict: forecast the } \\
\text { future, based on } \\
\text { extensive research } \\
\text { and using existing } \\
\text { knowledge }\end{array}$ & $\begin{array}{l}\text { Deepen and refine } \\
\text { existing knowledge } \\
\text { base through } \\
\text { leveraging existing } \\
\text { knowledge to } \\
\text { implement the } \\
\text { chosen strategy. }\end{array}$ & $\begin{array}{l}\text { Bierly \& Daly } \\
\text { (2007); Levinthal } \\
\text { \& March, (1993); } \\
\text { Smith \& } \\
\text { Tushman (2005); } \\
\text { Chandler } \text { et al. } \\
\text { (2011) }\end{array}$ \\
\hline $\begin{array}{l}\text { Predisposition } \\
\text { towards risk }\end{array}$ & $\begin{array}{l}\text { Innovation is } \\
\text { propelled by not } \\
\text { risking more } \\
\text { resources, than } \\
\text { founder can afford/is } \\
\text { prepared to lose }\end{array}$ & $\begin{array}{l}\text { Innovate and adopt a } \\
\text { long- term orientation, } \\
\text { as innovation takes a } \\
\text { longer time to pay-off }\end{array}$ & $\begin{array}{l}\text { Execute plan to } \\
\text { ensure goal } \\
\text { achievement }\end{array}$ & $\begin{array}{l}\text { Focus on execution } \\
\text { and adopt a short- } \\
\text { term orientation }\end{array}$ & $\begin{array}{l}\text { Kollmann, } \\
\text { Kückertz \& } \\
\text { Stäckmann } \\
\text { (2009); Walrave, } \\
\text { Oorschot \& } \\
\text { Romme (2011); } \\
\text { Wiltbank et al. } \\
\text { (2006) }\end{array}$ \\
\hline $\begin{array}{l}\text { Contingency } \\
\text { attitude }\end{array}$ & $\begin{array}{l}\text { Emergent approach } \\
\text { allows for } \\
\text { contingencies as } \\
\text { opportunities }\end{array}$ & $\begin{array}{l}\text { Create variety in } \\
\text { experience, as } \\
\text { unforeseen events and } \\
\text { serendipity create } \\
\text { opportunities to innovate }\end{array}$ & $\begin{array}{l}\text { Predictive, rational } \\
\text { approach ensures } \\
\text { reliability through } \\
\text { avoiding } \\
\text { contingencies } \\
\end{array}$ & $\begin{array}{l}\text { Create reliability } \\
\text { and stability in } \\
\text { experience }\end{array}$ & $\begin{array}{l}\text { Bontis, Crossan } \\
\text { \& Hulland } \\
(2002) ; \text { McGrath } \\
(2001) ; \text { Brettel et } \\
\text { al. }(2011)\end{array}$ \\
\hline $\begin{array}{l}\text { Progress in } \\
\text { practice }\end{array}$ & $\begin{array}{l}\text { Experiment to } \\
\text { discover attractive } \\
\text { opportunities and new } \\
\text { markets }\end{array}$ & $\begin{array}{l}\text { Experiment with new } \\
\text { approaches towards } \\
\text { technologies, business } \\
\text { processes or markets }\end{array}$ & $\begin{array}{l}\text { Seek utility } \\
\text { maximisation to } \\
\text { ensure the best course } \\
\text { of action }\end{array}$ & $\begin{array}{l}\text { Apply, optimise and } \\
\text { improve existing } \\
\text { competences, } \\
\text { technologies, } \\
\text { processes and } \\
\text { products }\end{array}$ & $\begin{array}{l}\text { Kuckertz. } \\
\text { Kohtamäki \& } \\
\text { Droege }(2010) ; \\
\text { Wiltbank et al. } \\
(2006) ; \text { Volery et } \\
\text { al. }(2015)\end{array}$ \\
\hline $\begin{array}{l}\text { Approach to } \\
\text { outsiders and } \\
\text { knowledge } \\
\text { acquisition }\end{array}$ & $\begin{array}{l}\text { Assumptions and } \\
\text { decisions are open to } \\
\text { change, based the pre- } \\
\text { commitment of self- } \\
\text { selected stakeholders }\end{array}$ & $\begin{array}{l}\text { Reconsider existing } \\
\text { beliefs and decisions, as } \\
\text { new information and } \\
\text { cooperation possibilities } \\
\text { emerge }\end{array}$ & $\begin{array}{l}\text { Outsiders are seen as } \\
\text { competitors; maintain } \\
\text { status quo; compete }\end{array}$ & $\begin{array}{l}\text { Elaborate on } \\
\text { existing beliefs and } \\
\text { decisions and } \\
\text { maintain status quo }\end{array}$ & $\begin{array}{l}\text { Lubatkin, Simsek, } \\
\text { Ling \& Veiga } \\
\text { (2006); Dew et al. } \\
\text { (2009); Turner et } \\
\text { al. (2013) }\end{array}$ \\
\hline
\end{tabular}

Table 1 demonstrates the relationship of effectual logic, exploration, causation and exploitation, based on the starting points of action, worldview, risk propensity, contingency attitude, progress in practice and approach to outsiders. Effectual logic is associated with uncertainty, while causation maximises the use of current data and knowledge to predict the future and minimise deviations from plans.

The literature continuously debates whether exploration and exploitation should be viewed as extremes (dualism view), or as complementary and coexisting (Gupta et al., 2006). Similarly, causation and effectuation approaches are often studied as opposites (Chandler et al., 2011), yet most individuals balance control logic (effectuation) with prediction logic (causation) in the innovation process (Wiltbank et al., 2006). In their systematic review of 119 papers on mechanisms for managing ambidexterity, Turner $e t$ al. (2013) report that while these two perspectives are theoretically distinguishable, in practice they function orthogonally. Sociocultural processes influence women's entrepreneurial cognitive ambidexterity, especially from a career-development perspective (Baù, Sieger, Eddleston \& Chirico, 2016).

\section{Career development}

Women's entrepreneurial decisions are influenced by their stage of career development, which is characterised by specific needs, values, preferences and priorities (Baù et al., 2016; Hall, 2002). Career development is a maturation process of implementing a person's self-concept by means of work roles (Savickas, 2002) and is associated with changes in self-efficacy. Changes in career and personal relationships are inherently linked to age (Levinson, Darrow, Klein, Levinson, \& McKee, 1978; Super, 1990). The literature discusses three career stages: the early exploration and establishment stage (teens to late thirties); the mid-career and maintenance stage (late thirties to late forties); and the late career stage (50 and above) (Baù et al., 2016; Gibson, 2003; Super, 1990). Bowen and Hisrich (1986) related the occupational structure of women entrepreneurs to career stages, while Jayawarna, Rouse and Kitching (2013) linked entrepreneur motivations to career life-course. For younger 
women, the early-career stage is characterised by uncertainty as they build professional competencies and have an open, experimental approach to entrepreneurial initiatives, due to limited experiential routines or schemas. For many women, family and motherhood considerations influence their career choices in this stage; for example, some may find employment less attractive after having children and decide to pursue independent entrepreneurship (Lewis, Harris, Morrison, Ho, Jawahar \& Al Ariss, 2015). During the midcareer stage, many women feel less constrained to pursue career goals (Martins, Eddleston \& Veiga, 2002), emphasising career achievement (Stroh \& Reilly, 1999) and building their careers by limiting risks and drawing on causation. During the late maintenance stage, women are expected to have mastered emotional responses to stressful situations (Baù et al., 2016), to have built a repertoire of behavioural strategies to bring about and execute entrepreneurial projects, and to be more likely to draw on both effectual and causal logic. Therefore it is hypothesised that:

$H 1_{a}$ : Women in the mature career stage are likely to make use of ambidexterity (effectual and causal logic) when dealing with entrepreneurial initiatives

Entrepreneurial self-efficacy (ESE) refers to how confident women are that they possess the abilities required for successful entrepreneurial initiatives (Wilson, Kickul \& Marlino, 2007). ESE is linked to their career stage (Baù et al., 2016). Work experience enhances women's ESE as their careers develop, encouraging them in their mid- and latecareer stages to dedicate more time and energy to their careers (Baù et al., 2016; Stroh \& Reilly, 1999). Wood and Bandura (1989) note that 'to be successful one not only must possess the required skills, but also a resilient self-belief in one's capability to exercise control over events to accomplish desired goals,' which is congruent with effectual action. ESE and its relationship to entrepreneurial activity has been studied from several perspectives, for example, how ESE fits with a particular career (Wilson et al., 2004), and how an opportunity is viewed (Mitchell \& Shepherd, 2010). Positive experiences and incidents increase perseverance and ESE, while failures and disappointments decrease ESE (Bandura, 1982). For example, Morris, Miyasaki, Watters \& Coombes et al. (2006) found the achievements of high-growth women's ventures had a positive reinforcing cycle, because goal achievement fuelled the setting of higher growth goals. In contrast, Baù et al. (2016) argue that women judge themselves harshly when they fail and are over-sensitive to negative feedback, which is referred to as self-derogatory bias. Women who persevere and demonstrate higher ESE are likely to use both effectual and causal logic in their entrepreneurial initiatives. Thus, it is hypothesised that:

$H 1_{b}$ : Women with high entrepreneurial self-efficacy are likely to display high levels of effectual and causal reasoning when dealing with entrepreneurial initiatives

\section{Cultural values}

Cultural values such as collectivism, individualism and ingroup values are interwoven with women's entrepreneurial cognition and behaviour (Bullough, Renko, \& Abdelzaher, 2014; Yousafzai et al., 2015). Collectivism is the belief that people belong to close, interconnected groups offering security and that group loyalty is valued over individual achievement (Gelfand, Bhawuk, Nishi \& Bechtold, 2004). For women involved in entrepreneurial activities, their close in-group (family, close friends and colleagues) can provide support and resources utilising this tight network of relationships. Yet collectivism can also limit women's entrepreneurial involvement by means of role prescriptions such as home duties (Brush et al., 2009). In contrast, individualism is the belief that people are independent and self-reliant, and individual goals should be valued above loyalty to a particular group. This value gives women the freedom to break away from traditional role prescriptions and acquire autonomy either in their careers or by means of entrepreneurial behaviour, with limited support from close networks. Bullough et al. (2014) found that in-group collectivism influences women's entrepreneurial behaviour. However, the freedom to pursue individual goals combined with support from the in-group provides the most conducive entrepreneurial environment.

South Africa is a multicultural society with 11 official languages (nine African languages and two Western languages) according to Statistics South Africa (2012). According to Adams et al. (2014) there are four distinguishable ethnic groups: 'White' (people of European descent), 'Black' (people of African descent), 'Coloured' (people of mixed ethnic origin), and 'Indian' (descendants of and immigrants from India and South-East Asia).

Ubuntu is a dominant cultural value among Black women, more so than in other ethnic groups (Adams et al., 2014). Ubuntu is an ancient African word, meaning I am what I am, because of who we are. Thus, individual achievements and goals attained only have significance when viewed in conjunction with the group's common good (Mangaliso, 2001). Ubuntu does not inhibit entrepreneurial behaviour, but rather influences its enactment (Urban, 2006). It is distinctive from extreme collectivism and individualism, and can be regarded as 'moderate' collectivism (Bullough et al., 2014). Black women tend to prefer collectivist social behavioural norms, specifically tradition preservation, work and development. In contrast, White women prefer personalgrowth independence above social-relational norms, and tend to be more individualistic (Adams et al., 2014; Valchev, Nel, Van de Vijver, Meiring, De Bruin, \& Rothmann, 2013). Ubuntu values therefore enable access to collective resources when Black women are involved in entrepreneurial activities, provided they are supported by the in-group (Bullough et al., 2014). Obtaining resources from network relationships is consistent with effectual logic. In addition, women with Ubuntu values favour tradition preservation, which creates reliability by considering existing initiatives. Therefore it is hypothesised that: 
$H_{2 a}$ : Women with Ubuntu values are likely to display effectual and causal reasoning when dealing with entrepreneurial initiatives

Women's relationship skills in cultivating networks are important for creating new firms and markets (Hampton, Cooper \& McGowan, 2009; Klyver \& Terjesen, 2007). Relationship skills refer to the ability to interact effectively with others and they exert a strong influence on success in entrepreneurial initiatives (Westerberg \& Wincent, 2008). Given their years of developing diverse networks, mature women are likely to apply a relational, consultative approach in entrepreneurial initiatives (Brunetto \& Farr-Wharton, 2007; Brush, 1992; Verheul, Uhlaner \& Thurik, 2005). They are good at developing and maintaining relationships in which social linkages ensure greater resource availability (Sorenson, Folker \& Brigham, 2008). Similarly, women who hold Ubuntu values are able to adjust to contingencies and respond to a variety of social stimuli that require ambidexterity in logic. These skills are crucial to building goodwill (Walter, Auer \& Ritter, 2006) that encourages a potential network partner's willingness to commit to a new initiative. Thus Ubuntu values and relational processes draw on effectual logic to gain interest and persuade a business partner to participate in a business relationship. However, causal logic is required to create a feeling of dependability, credibility and goodwill. Therefore it is hypothesised that:

$H 2_{b}$ : Women with high levels of relationship skills are likely to display both effectual and causal reasoning when dealing with entrepreneurial initiatives

The research model representing these hypotheses is depicted in Figure I.

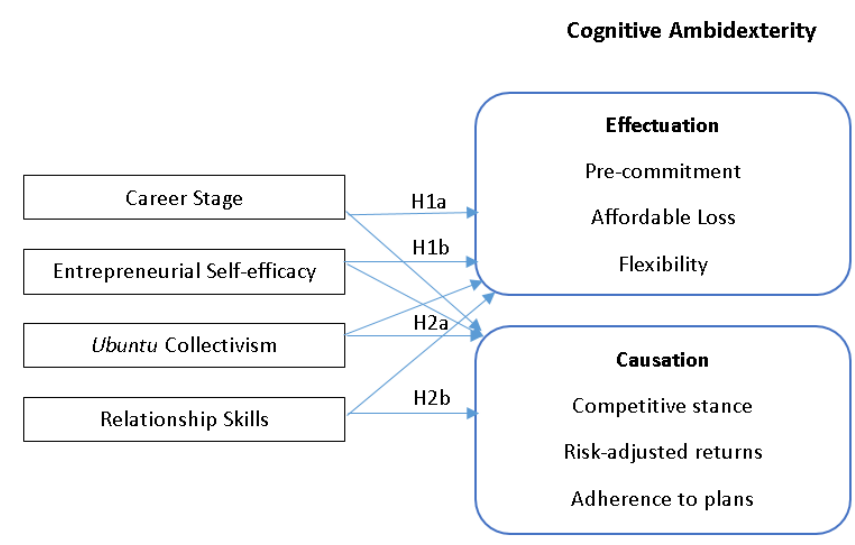

Figure 1: Model of hypothesized relationships

\section{Research design and methodology}

Entrepreneurial South African women provide an ideal context in which to test the hypotheses illustrated in Figure 1. First, entrepreneurial activity among South African women is high due to opportunity entrepreneurship (Herrington, Kew \& Kew, 2014); many women own a business (FinScope South Africa, 2010); and are economically active (women comprise $45 \%$ of all those employed). Their business behaviour is also supported by an enabling environment (Simo Kenge, 2016). Second, entrepreneurial activity among South African women is critical for the country's future economic development. Hence, understanding the influence of career development and cultural values on ambidexterity could help improve independent entrepreneurship and organisational innovation. Third, Ubuntu's impact on women's cognitive ambidexterity in a culturally diverse society (with 11 official languages) can be examined. The first language of $77.9 \%$ of the population is an African language (North Sotho, South Sotho, Tswana, Ndebele, Swati, Xhosa, Zulu, Tsonga or Venda); of the remainder, $21.5 \%$ speak Afrikaans or English as a first language (Statistics South Africa, 2012).

To assess the proposed hypotheses, women entrepreneurs were surveyed using a stratified sampling approach across the five most economically active provinces: Gauteng, Western Cape, Eastern Cape, Kwa-Zulu Natal and North-West provinces (Statistics South Africa, 2012). Women involved in entrepreneurial initiatives in the last 18 months were invited to participate through chambers of commerce and the National Businesswomen's Association. They could answer a questionnaire online, by telephone, or face-to-face. To maximise the response rate, respondents were allowed to choose the most convenient response option for them and were offered a summary of the findings, made available online and via the referring associations. Additionally, respondents who had not returned their questionnaires by the specified date were followed up, by sending a reminder to the whole group, thanking those who responded and urging nonrespondents to complete the survey. Follow-up increased responses from 269 to 309 usable questionnaires, an acceptable response rate of $11.29 \%$ (Hamilton, 2009).

To compensate for this study's reliance on self-reported data from single informants and thus the potential influence of common method bias (Podsakoff, MacKenzie, Lee \& Podsakoff, 2003), procedural (questionnaire design, pilot study and ensuring anonymity) and statistical remedies were used. For the questionnaire, items to measure key constructs were taken from existing scales, except for cognitive ambidexterity, for which measures were drawn from Chandler et al.'s (2011) new scale. After a pilot study among 33 women, the wording of some items were simplified to reflect the local context, the layout was improved and the wording of ambiguous items were changed. In addition, two entrepreneurship researchers assessed the questionnaire items for content validity as suggested by Nunnally (1978). Respondents were assured of anonymity to reduce evaluation apprehension, which prevented methodological separation of data collection, but is recommended to reduce bias (Podsakoff et al., 2003, p. 887). The trade-off for anonymity was considered more important than methodological separation because the involvement of the respondents was essential for data collection.

Respondents were asked to complete the questionnaire based on their involvement in an entrepreneurial initiative. They were asked to indicate their level of autonomy and to classify the type of initiative in one of four categories, namely a new 
marketing or business development initiative, a new project or process, a new human resource initiative, or a completely new venture. Initiatives reported on included new marketing or business developments (21.3\%), new ventures $(34.6 \%)$, new product introductions (13.6\%), new processes and projects $(22.1 \%)$, and new human resource initiatives $(8.4 \%)$. The majority of initiatives were characterised by novelty $(61.2 \%)$. Most respondents had either sole responsibility $(40.5 \%)$ for the initiative or functioned as the team leader (42.4\%), which indicated a high level of autonomy. Because autonomy is a key theme in the entrepreneurship literature (Patterson \& Mavin, 2009), this sample characteristic adds to the validity of the results. Most women were older than 30 years $(64.1 \%)$, with the majority between 31 and 45 years $(53.7 \%)$. Regarding formal education levels, $20.7 \%$ and $23.3 \%$ had completed primary and secondary school, respectively; $35.3 \%$ held tertiary certificates; and $20.7 \%$ had a bachelor degree or higher. About one-third (34\%) had 7 years or more of management experience. These demographic characteristics are similar to those in the Global Entrepreneurship Monitor reports (GEM) (Herrington et al., 2014), although the women in the current study generally had higher levels of education and were more experienced.

\section{Operationalisation and measures}

An overview of the items to assess the composite constructs is provided in Appendix 1. Ambidexterity - Exploration was measured with effectuation items and exploitation with causation items, using the scale developed by Chandler $e t$ al. (2011), as discussed earlier. All questionnaire items were scored on a five-point Likert scale from 1 (Strongly disagree) to 5 (Strongly agree). The revised Chandler et al. (2011) scale consisted of 13 items, 5 items measuring causation, and 2 items for each effectuation's sub-dimensions: experimentation, affordable loss, flexibility for contingencies, and pre-commitments from stakeholders, which represented the dependent variables. The discriminant validity of the scale was assessed using exploratory factor analysis (pattern matrix in Table 2). The dependent variables loaded onto four factors: causation, affordable loss, flexibility for contingencies and pre-commitments. However, experimentation did not load satisfactorily. The Cronbach alpha coefficients reported in Table 3 show acceptable internal consistency $(\alpha>0.70)$ for all the dependent variables, except pre-commitment ( $\alpha=0.65$ ). However, this value was considered acceptable because only two items were used to measure this construct (see Nunnally, 1978).

Table 2: Pattern matrix of factor loadings for the dependent variables

\begin{tabular}{|c|c|c|c|c|}
\hline Items & $\begin{array}{l}\text { Factor } 1 \\
\text { Causation } \\
\end{array}$ & $\begin{array}{l}\text { Factor 2 } \\
\text { Affordable loss }\end{array}$ & $\begin{array}{l}\text { Factor } 3 \\
\text { Flexibility }\end{array}$ & $\begin{array}{l}\text { Factor } 4 \\
\text { Pre-commitments }\end{array}$ \\
\hline Causation [Plan business strategies, before taking action.] & 0.930 & -0.015 & 0.060 & -0.048 \\
\hline $\begin{array}{l}\text { Effectuation [Considered different business models for my } \\
\text { initiative.] }\end{array}$ & 0.415 & 0.143 & -0.018 & 0.098 \\
\hline $\begin{array}{l}\text { Causation [Implemented control processes to make sure } \\
\text { objectives were met.] }\end{array}$ & 0.395 & -0.022 & -0.171 & 0.248 \\
\hline $\begin{array}{l}\text { Causation [Select long-run opportunity that would provide the } \\
\text { best returns.] }\end{array}$ & 0.368 & -0.035 & -0.223 & -0.006 \\
\hline $\begin{array}{l}\text { Effectuation [Was careful not to commit more resources than } \\
\text { I could afford to lose.] }\end{array}$ & -0.086 & 0.771 & -0.123 & -0.014 \\
\hline $\begin{array}{l}\text { Effectuation [Was careful not to risk more money than I am } \\
\text { willing to lose with the initial idea.] }\end{array}$ & 0.100 & 0.738 & 0.059 & 0.024 \\
\hline $\begin{array}{l}\text { Causation [Developed a strategy to best take advantage of } \\
\text { resources and capabilities.] }\end{array}$ & 0.078 & 0.017 & -0.796 & 0.034 \\
\hline $\begin{array}{l}\text { Effectuation [Adapted what I was doing to the resources } \\
\text { available for the project.] }\end{array}$ & 0.000 & 0.071 & -0.597 & 0.016 \\
\hline $\begin{array}{l}\text { Effectuation [Made use of agreements with business partners } \\
\text { to reduce uncertainty.] }\end{array}$ & -0.039 & -0.058 & -0.136 & 0.678 \\
\hline $\begin{array}{l}\text { Effectuation [Reduced the amount of uncertainty by using a } \\
\text { substantial number of agreements with customers, suppliers } \\
\text { and other organisations.] }\end{array}$ & 0.034 & 0.061 & 0.093 & 0.572 \\
\hline
\end{tabular}

Career stages was reflected by three age categories for early, mid- and late career stages ( $<30,31-45$, and $>46$ years) (see Savickas, 2002). Entrepreneurial self-efficacy was measured using Westerberg, Singh and Hackner's (1997) scale $($ Cronbach alpha coefficient $=0.87)$.

Ubuntu was assessed by the two proxies 'ethnic group' and 'language', measures typically used by social psychologists (Adams et al., 2014; Vogt \& Laher, 2009). These authors show that the African group (Sotho, Tswana, Xhosa, Zulu speakers) tend to ascribe to the philosophy of Ubuntu, defined as moderate collectivism (Eaton \& Louw, 2000; Valchev et al., 2013), while the White ethnic group (Afrikaans and
English-speaking) tend to value individualism. For ethnic grouping, 1 was coded to reflect individualism, while 2 was used for Ubuntu collectivism, and 3 to indicate a small number of immigrants. Similarly, women from different language groups were coded to represent speakers of Afrikaans (1), English (2), African languages (3) (Xhosa, Zulu, Tswana, Sotho) and European languages (4), where African languages represents Ubuntu collectivism and Afrikaans, English and European languages represent individualism. Relationship skills was measured with 7 items sourced from Walter et al.'s (2006) Network Capability scale $($ Cronbach alpha $=0.86)$. 
Variables documented in the literature to influence cognition were controlled for. Autonomy influences entrepreneurial behaviour (Patterson \& Mavin, 2009) and was measured by the role women had in the initiative (leader, sole responsibility or team member). The type of entrepreneurship (independent or corporate) women are involved in, influences their risk propensity (Douglas \& Fitzsimmons, 2013), which is related to affordable loss, and was assessed by whether the entrepreneurial initiative was undertaken independently or as part of their employment. Human capital factors, such as formal education and managerial and entrepreneurial experience, affect cognition (Davidsson \& Honig, 2003; Dew et al., 2009) and were measured by the level of formal education and the number of years of managerial and entrepreneurial experience. Novelty also influences cognition because it relates to uncertainty (Brettel et al., 2011) and was coded with 1 (novel projects) or 2 (non-novel initiatives).
The data were analysed using IBM SPSS version 22. The hypotheses were assessed using hierarchical regression analysis, controlling for autonomy, the type of entrepreneurship, management and entrepreneurial experience, formal education and novelty of the initiative. Differences between career stage, cultural values and cognitive ambidexterity were assessed using one-way analysis of variance and Tukey HSD post hoc tests.

\section{Results}

The correlation coefficients between the constructs in the study indicate causation was significantly correlated with all the effectuation constructs, including flexibility, precommitments and affordable loss, suggesting that causation and effectuation co-exist within a woman's mind when making decisions about entrepreneurial initiatives (Table 3).

Table 3: Descriptive statistics

\begin{tabular}{l|l|l|l|l|l|l|l|l}
\hline Constructs & $\begin{array}{l}\text { Mean } \\
\text { score }\end{array}$ & SD & $\begin{array}{l}\text { Cronbach } \\
\text { Alpha }\end{array}$ & \multicolumn{3}{l}{ Correlation coefficients } & $\mathbf{3}$ \\
\hline & & & & $\mathbf{1}$ & $\mathbf{2}$ & & \\
\hline 1 Self-efficacy & 4.262 & 0.549 & 0.87 & & & & \\
\hline $\begin{array}{l}\text { 2 Relationship } \\
\text { skills }\end{array}$ & 4.056 & 0.676 & 0.86 & $0.523^{* *}$ & & & \\
\hline $\begin{array}{l}\text { 3 Pre- } \\
\text { commitments }\end{array}$ & 3.568 & 0.911 & 0.65 & $0.209^{* *}$ & $0.272^{* *}$ & & & \\
\hline 4 Affordable loss & 3.963 & 0.964 & 0.75 & $0.111^{*}$ & $0.239^{* *}$ & $0.189^{* *}$ & & \\
\hline 5 Flexibility & 4.218 & 0.711 & 0.74 & $0.431^{* *}$ & $0.417^{* *}$ & $0.232^{* *}$ & $0.299^{* *}$ & 1.0 \\
\hline 6 Causation & 4.131 & 0.698 & 0.71 & $0.364^{* *}$ & $0.403^{* *}$ & $0.310^{* *}$ & $0.303^{* *}$ & $0.512^{* *}$ \\
\hline
\end{tabular}

Notes: $\mathrm{n}=309 ; *$ and $* *$ indicate significance of correlation at $p<0.05$ and 0.01 level respectively (2-tailed) ; $\dagger \mathrm{p}<0.10$.

Table 4: Hierarchical regression analysis on variables for cognitive ambidextrous decision-making

\begin{tabular}{|c|c|c|c|c|c|c|c|c|}
\hline \multirow[t]{2}{*}{ Variables } & \multicolumn{2}{|c|}{ Pre-commitment } & \multicolumn{2}{|c|}{ Affordable Loss } & \multicolumn{2}{|c|}{ Flexibility } & \multicolumn{2}{|l|}{ Causation } \\
\hline & Model 1 & Model 2 & Model 1 & Model 2 & Model 1 & Model 2 & Model 1 & Model 2 \\
\hline Intercept & 4.194 & 3.134 & 3.792 & 1.736 & 4.397 & 1.584 & 4.036 & 1.333 \\
\hline \multicolumn{9}{|l|}{ Control variables } \\
\hline Autonomy & $-0.148^{*}$ & $-0.145 *$ & 0.011 & 0.022 & -0.033 & -0.023 & -0.099 & -0.087 \\
\hline $\begin{array}{l}\text { Type of } \\
\text { entrepreneurship }\end{array}$ & -0.094 & $-0.122^{\dagger}$ & 0.077 & 0.062 & .085 & 0.042 & 0.017 & -0.012 \\
\hline $\begin{array}{l}\text { Management } \\
\text { experience }\end{array}$ & -0.031 & -0.037 & 0.011 & -0.055 & -0.046 & -0.061 & -0.037 & $-0.109 \dagger$ \\
\hline $\begin{array}{l}\text { Entrepreneurial } \\
\text { experience }\end{array}$ & 0.045 & -0.064 & 0.066 & -0.014 & 0.097 & -0.078 & $0.140 *$ & -0.013 \\
\hline Education & -0.005 & -0.026 & $-0.117 \dagger$ & -0.086 & -0.071 & $-0.105 \dagger$ & -0.021 & -0.022 \\
\hline Novelty & -0.037 & -0.038 & 0.004 & 0.004 & -0.110 & -0.099 & 0.019 & 0.020 \\
\hline \multicolumn{9}{|l|}{$\begin{array}{l}\text { Independent } \\
\text { variables }\end{array}$} \\
\hline $\begin{array}{l}\text { Age (proxy for } \\
\text { career stage) }\end{array}$ & & -0.088 & & $0.159 * *$ & & 0.036 & & $0.163 * *$ \\
\hline $\begin{array}{l}\text { Language (proxy for } \\
\text { Ubuntu) }\end{array}$ & & -0.051 & & 0.073 & & $0.114 *$ & & $0.096^{\dagger}$ \\
\hline ESE & & 0.082 & & 0.028 & & $0.330 * *$ & & $0.241 * *$ \\
\hline Relationship skills & & $0.265 * *$ & & $0.220 * *$ & & $0.268 * *$ & & $0.283 * *$ \\
\hline $\mathrm{R}^{2}$ & 0.048 & 0.139 & 0.028 & 0.102 & 0.025 & 0.284 & 0.029 & 0.239 \\
\hline $\mathrm{R}^{2}$ change & 0.048 & 0.092 & 0.028 & 0.073 & 0.025 & 0.260 & 0.029 & 0.210 \\
\hline F change (sig) & $2.529 *$ & $7.935 * *$ & 1.475 & $6.064 * *$ & 1.266 & $27.029 * *$ & 1.501 & $20.616^{* *}$ \\
\hline
\end{tabular}

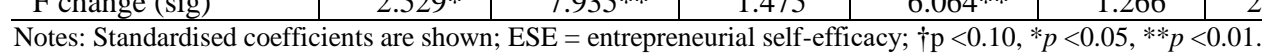


For pre-commitments, the results for Model 1, with control variables, was significant $\left(\Delta \mathrm{R}^{2}=4.8 \%, p<0.05\right)$, but the addition of the predictor variables made a significant contribution abeyond this base model $\left(\Delta \mathrm{R}^{2}=9.2 \% ; p<0.01\right)$. In the full model, the significant variable was relationship skills (Table 4). These results provide partial support for hypothesis $2 \mathrm{~b}$; however, hypothesis $1 \mathrm{~b}$ was not supported.

For affordable loss, the base model was not significant, but improved significantly when adding the predictor variables $\left(\Delta \mathrm{R}^{2}=7.3 \% ; p<0.01\right)$. Specifically, career stage and relationship skills were associated with affordable loss, lending partial support to hypotheses $1 \mathrm{a}$ and $2 \mathrm{~b}$ (Table 4).

The base model for flexibility was not significant. The addition of predictor variables made a significant contribution $\left(\Delta \mathrm{R}^{2}=26 \% ; p<0.01\right)$. In the full model language as a proxy for cultural values, ESE and relationship skills showed significant associations with flexibility, supporting hypotheses $1 \mathrm{~b}, 2 \mathrm{a}$ and $2 \mathrm{~b}$. The predictor variables explained $28.4 \%$ of the variance for this construct (Table 4 ).

For causation, the base model was not significant, but the addition of the predictor variables made a significant contribution $\left(\Delta \mathrm{R}^{2}=21 \% ; p<0.01\right)$. In the full model career stage, language, ESE and relationship skills showed significant associations. These results provide partial support for hypotheses 1a, 1b, 2a and 2b, respectively (Table 4).

\section{Comparison of career stage and cultural differences among women}

One-way analysis of variance (Table 5) enabled the assessment of hypotheses 1a and 2a related to career stage and cultural values (Ubuntu collectivism vs individualism).

The results of the ANOVA and Tukey HSD post hoc tests revealed that pre-commitment was marginally higher $(p<$ 0.10 ) among young women than among mid-career women. Affordable loss and causation among mature women were significantly higher than among young women. Mature women were also more likely to utilise affordable loss and causation than were mid-career women. In contrast, no significant differences between groups were observed for flexibility. These results support Hypothesis $1_{\mathrm{a}}$, that is, that mature women use ambidexterity (both effectual and causal logic) in their entrepreneurial initiatives (Table 5).

Ethnic group and language were used as proxies to assess the influence of cultural values on ambidexterity. No significant differences were found for effectuation when comparing ethnic groups. However, the mean score for causation was significantly higher in the Ubuntu group than in the individualistic group. The three language groups, as proxies for cultural values, showed no significant differences for precommitment. However, for affordable loss, African-language speakers scored marginally higher than Afrikaans-speaking women. For flexibility and causation, significant differences were observed between African-language speakers and both Afrikaans- and English-speaking women. Thus, the results (see Table 5) provide partial support for Hypothesis 2a (i.e. women with Ubuntu values displayed higher causation, flexibility and affordable loss scores, but showed no difference in pre-commitment).

Table 5: Mean comparisons of career stages and cultural value differences

\begin{tabular}{|c|c|c|c|}
\hline \multirow{2}{*}{$\begin{array}{l}\text { Variable } \\
\text { Pre- } \\
\text { commitment }\end{array}$} & \multicolumn{2}{|l|}{ Career stage $^{a}$} & \multirow{2}{*}{$\begin{array}{l}\begin{array}{l}\text { Mean } \\
\text { Difference }\end{array} \\
-0.296 \\
0.403^{\dagger}\end{array}$} \\
\hline & $\begin{array}{l}\text { Mature } \\
(3.595) \\
\text { Young }\end{array}$ & $\begin{array}{l}\text { Early } \\
(3.891) \\
\text { Mid-career } \\
(3.488) \\
\end{array}$ & \\
\hline $\begin{array}{l}\text { Affordable } \\
\text { Loss }\end{array}$ & $\begin{array}{l}\text { Mature } \\
(4.149)\end{array}$ & $\begin{array}{l}\text { Early } \\
(3.672) \\
\text { Mid-career } \\
(3.895)\end{array}$ & $\begin{array}{l}0.477^{*} \\
0.254 \dagger\end{array}$ \\
\hline Flexibility & $\begin{array}{l}\text { Mature } \\
(4.297)\end{array}$ & $\begin{array}{l}\text { Early } \\
(4.281) \\
\text { Mid-career } \\
(4.154) \\
\end{array}$ & $\begin{array}{l}0.016 \\
0.144\end{array}$ \\
\hline \multirow[t]{2}{*}{ Causation } & $\begin{array}{l}\text { Mature } \\
(4.331)\end{array}$ & $\begin{array}{l}\text { Early } \\
(4.008) \\
\text { Mid-career } \\
(4.021)\end{array}$ & $\begin{array}{l}0.323^{*} \\
0.310^{*}\end{array}$ \\
\hline & \multicolumn{2}{|c|}{$\begin{array}{l}\begin{array}{l}\text { Language group (proxy for } \\
\text { cultural values) }\end{array} \\
\end{array}$} & \\
\hline $\begin{array}{l}\text { Pre- } \\
\text { commitment }\end{array}$ & $\begin{array}{l}\text { African } \\
(3.609)\end{array}$ & $\begin{array}{l}\text { Afrikaans } \\
(3.411) \\
\text { English } \\
(3.599) \\
\end{array}$ & $\begin{array}{l}\mathrm{ns} \\
\mathrm{ns}\end{array}$ \\
\hline $\begin{array}{l}\text { Affordable } \\
\text { Loss }\end{array}$ & $\begin{array}{l}\text { African } \\
(4.125)\end{array}$ & $\begin{array}{l}\text { Afrikaans } \\
(3.759) \\
\text { English } \\
(3.936) \\
\end{array}$ & $\begin{array}{l}-0.366 \dagger \\
\text { ns }\end{array}$ \\
\hline Flexibility & $\begin{array}{l}\text { African } \\
(4.422)\end{array}$ & $\begin{array}{l}\text { Afrikaans } \\
(3.973) \\
\text { English } \\
(4.182) \\
\end{array}$ & $\begin{array}{l}0.449^{*} \\
0.240^{*}\end{array}$ \\
\hline Causation & $\begin{array}{l}\text { African } \\
(4.339)\end{array}$ & $\begin{array}{l}\text { Afrikaans } \\
(4.022) \\
\text { English } \\
(4.043)\end{array}$ & $\begin{array}{l}0.316^{*} \\
0.296^{*}\end{array}$ \\
\hline & $\begin{array}{l}\text { Ethnic grol } \\
\text { cultural value }\end{array}$ & (proxy for & \\
\hline Causation & $\begin{array}{l}\text { Ubuntu } \\
\text { Collectivism } \\
(4.248)\end{array}$ & $\begin{array}{l}\text { Individualism } \\
(4.024)\end{array}$ & $-0.224 *$ \\
\hline
\end{tabular}

Notes: ${ }^{a}$ Career stages are early career $(\leq 30$ years $)$, mid-career $(31-45$ years $)$ and mature career $(\geq 46$ years $) ; \mathrm{ns}=$ non-significant; ${ }^{\dagger} p<0.10 ;{ }^{*} p<0.05$.

\section{Discussion}

This study examined the cognitive ambidexterity that South African women of diverse cultural backgrounds use in entrepreneurial initiatives, and how their initiatives are influenced by their career stage and cultural values. The findings of this study suggest that effectuation and causation, as ambidextrous constructs, function in an orthogonal manner in practice because no resource trade-off between effectuation and causation was apparent. 
In terms of career development theory (Hall, 2002; Super, 1990), the findings reveal that women in the mature career stage are adept at balancing effectual and causal reasoning in their entrepreneurial initiatives. These findings confirm those reported by Turner et al. (2013) and Volery et al. (2015). These women are comfortable using affordable loss, flexibility and causation, because they are confident, have extensive relationships and diverse networks to draw on, and can see patterns in implementing entrepreneurial initiatives. They must draw on their past repertoire of mental models to extrapolate outcomes and implement future projects. This repertoire of mental models helps mature women justify the merits of their entrepreneurial initiatives. Additionally, younger women in the early stage of their career were more likely to use effectual pre-commitment for entrepreneurial initiatives. They draw on their relationship skills to obtain early assurances from stakeholders, and reconsider their existing beliefs as new cooperation possibilities emerge, which is consistent with effectuation principles (Sarasvathy, 2008; Turner et al., 2013)

These findings confirm the relevance of cultural values for women's entrepreneurial activities, specifically for South African women who subscribe to Ubuntu values can balance affordable loss, flexibility and causation while drawing on their entrepreneurial self-efficacy and relational skills. These women drew on Ubuntu values to gain access to collective resources from their in-groups, lowering perceived risks and turning threatening contingencies into opportunities to enhance their entrepreneurial initiatives. These findings concur with those reported by Bullough et al. (2014) and Volery et al. (2015).

Practically, the study has three implications for entrepreneurial women, leaders of networks such as the Business Women's Association and Chambers of Commerce and educators. For women, the findings suggest that greater awareness throughout their careers of their preferred approach to ambidexterity would benefit reflection and mentoring. Younger women, more open to involving stakeholders through pre-commitment, would benefit from mentoring by mature business women. The mature women possess a repertoire of mental models to navigate the challenges that arise in entrepreneurial initiatives, by using both effectual flexibility and causation. For network leaders among South African women entrepreneurs, the findings suggest that Ubuntu, as a cultural value, can be harnessed, because it enables community resources from strong in-group relationships to be used in entrepreneurial initiatives. Beyond the South African context, cultural values are a resource that business women can draw upon and share with others by networking and empowering women to address perceived barriers to entrepreneurial behaviour. For entrepreneurship educators, the findings show that cognitive ambidexterity, using both effectual and causal decision-making, should be developed among women to allow them to pursue entrepreneurial initiatives both in and outside organisations. By nurturing explorative, effectual, analytical and causal skills, and by developing entrepreneurial self-efficacy, entrepreneurial leadership can be developed. Educators should develop curricula, simulations and role-play exercises that develop an awareness among entrepreneurship students of the influence of career stage and cultural values on entrepreneurship initiatives. Enabling students to draw on their personal and cultural values as resources may contribute to developing more imaginative entrepreneurial initiatives.

From a theoretical perspective, these findings contribute to the literature on individual cognitive ambidexterity by relating the effectuation principles to exploration and exploitation. This study builds on previous work by articulating that exploration consists of independent dimensions such as pre-commitment of stakeholders, effectuation and flexibility. It also highlights that cognitive ambidexterity is not fully captured by exploration and exploitation. Furthermore, this study shows that ambidexterity dimensions are more likely to be orthogonal rather than opposites, a result that concurs with the work of Agogue, Lundqvist and Middleton (2015). The study also contributes to the growing literature on entrepreneurship and career development by showing how career stages influence cognitive ambidexterity for entrepreneurial initiatives. Additionally, the study extends the literature on cultural values and entrepreneurship by showing how Ubuntu, an African collectivist value, influences the cognitive ambidexterity of Black South African women, furthering the work of other researchers in this area (Adams et al., 2014; Bullough et al., 2014; Urban, 2006).

\section{Limitations and future research}

Despite the insights offered by this study, caution should be exercised when generalising the results beyond the current sample. First, this study used a cross-sectional survey to explore how women's career stages and cultural values influence their cognitive ambidexterity. Given the limitations of this research design, future researchers should consider experimental or conjoint analysis to study the choices women make in entrepreneurial initiatives. The measures used in this study could not reliably assess effectual experimentation. Furthermore, our findings highlight the crucial role of relationships for ambidexterity, suggesting that a socialconstructivist epistemology is suitable for researching the phenomenon.

Additionally, as the independent variables only partly explained the variation in pre-commitment and affordable loss, future researchers should study the effectual dimensions independently and use qualitative methods such as ethnography to capture how these dimensions unfold in practice. Research should also investigate the antecedents of the dimensions of cognitive ambidexterity and explore factors related to affordable loss, obtaining pre-commitments from stakeholders, and remaining flexible in the face of contingencies. This research study used proxies for cultural values. Incorporating more substantive measures of cultural values in future studies would be valuable. Finally, this study did not compare the cultural values of women in different countries; and therefor the findings are limited to one multicultural context. Exploring the role of Ubuntu in other African countries (Urban, 2006) might reveal novel insights, 
given the limited theorisation of Ubuntu as a cultural value. Studies in the Chinese context have researched how 'guanxi' differs in its use of social relationships in a Western setting. Similarly, more research is needed on the influence of African cultural values and social relationships in entrepreneurship.

\section{Conclusion}

Entrepreneurial ambidexterity is a form of mental multitasking that is part of the demands of workplace innovation for many women. This study assessed the influence of career stage and cultural values on women's cognitive ambidexterity. It provides a theoretical basis for individual ambidexterity by drawing on effectuation as an emergent entrepreneurship theory, and emphasises the complementary nature of effectual and causal approaches, as well as the influence of career development and Ubuntu values for women. In adopting a strategic essentialist perspective, the study shows how heterogeneous groups of women employ ambidexterity. However, many unanswered questions remain in this field, providing opportunities for future research.

\section{References}

Adams, B.G., Van de Vijver, F.J., de Bruin, G.P. \& Torres, C.B. 2014. 'Identity in descriptions of others across ethnic groups in South Africa', Journal of Cross-Cultural Psychology, 45(9): 14111433.

Agogue, M., Lundqvist, M. \& Middleton, K.W. 2015. 'Mindful deviation through combining causation and effectuation: A design theory-based study of technology entrepreneurship', Creativity and Innovation Management, 24(4): 629-644.

Appelbaum, S.H., Marchionni, A. \& Fernandez, A. 2008. 'The multi-tasking paradox: Perceptions, problems and strategies', Management Decision, 46(9): 1313-1325.

Bandura, A. 1982. 'Self-efficacy mechanism in human agency', American Psychologist, 37(2): 122-147.

Baù, M., Sieger, P., Eddleston, K.A. \& Chirico, F. 2016. 'Fail but try again? The effects of age, gender, and multiple-owner experience on failed entrepreneurs' re-entry', Entrepreneurship Theory and Practice. doi: 10.1111/etap.12233

Bierly, P. \& Daly, P. 2007. 'Alternative knowledge strategies, competitive environment and organizational performance in small manufacturing firms', Entrepreneurship, Theory and Practice, 31(4): 493-516.

Bledow, R., Frese, M., Anderson, N.R., Erez, M. \& Farr, J.L. 2009. 'A dialectic perspective on innovation: Conflicting demands, multiple pathways, and ambidexterity', Industrial and Organizational Psychology: Perspectives on Science and Practice, 2(3): 305-337.

Bock, B.B. 2004. 'Fitting in and multi-tasking: Dutch farm women's strategies in rural entrepreneurship', Sociologia Ruralis, 44(3): 245260.

Bontis, N., Crossan, M. \& Hulland, J. 2002. 'Managing an organizational learning system by aligning stocks and flows', Journal of Management Studies, 39(4): 437-469.
Boumgarden P., Nickerson J. \& Zenger T.R. 2012. 'Sailing into the wind: Exploring the relationships among ambidexterity, vacillation, and organizational performance', Strategic Management Journal, 33(6): 587- 610.

Bowen, D.D. \& Hisrich, R.D. 1986. 'The female entrepreneur: A career development perspective', Academy of Management Review, 11(2): 393-407.

Braches, B. \& Elliott, C. 2016. 'Articulating the entrepreneurship career: A study of German women entrepreneurs', International Small Business Journal, doi: 0266242616651921

Brettel, M., Mauer, R., Engelen, A. \& Kupper, D. 2011. 'Corporate effectuation: Entrepreneurial action and its impact on R\&D project performance', Journal of Business Venturing, 27(2): 167-184.

Brunetto, Y. \& Farr-Wharton, R. 2007. 'The moderating role of trust in entrepreneurs' decision-making about collaboration', Journal of Small Business Management, 45(3): 362-388.

Brush, C.G. 1992. 'Research on women business owners: Past trends, a new perspective and future directions', Entrepreneurship Theory and Practice, 16(4): 5-30.

Brush, C.G., de Bruin, A. \& Welter, F. 2009. 'A gender-aware framework for women's entrepreneurship', International Journal of Gender and Entrepreneurship, 1(1): 8-24.

Bullough, A., Renko, M. \& Abdelzaher, D. 2014. 'Women's business ownership: Operating within the context of institutional and in-group collectivism', Journal of Management, doi: $10.117 / 0149206314561302$

Chandler, G.N., DeTienne, D.R., McKelvie, A. \& Mumford, T.V. 2011. 'Causation and effectuation processes: A validation study', Journal of Business Venturing, 26(3): 375-390.

Daniel, E.M., Di Domenico, M. \& Sharma, S. 2014. 'Effectuation and home-based online business entrepreneurs', International Small Business Journal, 33(8): 799-823.

Davidsson, P. \& Honig, B. 2003. 'The role of social and human capital among nascent entrepreneurs', Journal of Business Venturing, 18(3): 301-331.

Dew, N., Read S, Sarasvathy, S.D. \& Wiltbank, R. 2009. 'Effectual versus predictive logics in entrepreneurial decision-making: Differences between experts and novices', Journal of Business Venturing, 24(4): 287-309.

Douglas, E.J. \& Fitzsimmons, J.R. 2013. 'Intrapreneurial intentions versus entrepreneurial intentions: Distinct constructs with different antecedents', Small Business Economics, 41 (1): 115-132.

Eaton, L., \& Louw, J. 2000. 'Culture and self in South Africa: Individualism-collectivism predictions', Journal of Social Psychology, 140: 210-217.

FinScope South Africa. 2010. Small Business Survey 2010, Finmark Trust, Midrand.

Gelfand, M.J., Bhawuk, D.P.S., Nishi, L.H. \& Bechtold, D.J. 2004. Individualism and collectivism, in House, R. J. Hanges, P.J., Javidan, M., Dorfman, P.W. \& Gupta, V. (Eds.), Culture, Leadership and Organizations: The GLOBE Study of 62 Societies, Sage, Thousand Oaks, CA: 437-512. 
Gibson, D.E. 2003. 'Developing the professional self-concept: Role model construals in early, middle, and late career stages', Organization Science, 14(5): 591-610.

Gupta, A.K., Smith, K.G. \& Shalley, C.E. 2006. 'The interplay between exploration and exploitation', Academy of Management Journal, 49: 693-706.

Hall, D.T. 2002. Careers In and Out of Organizations, Sage, Thousand Oaks, CA.

Hamilton, M.B. 2009. 'Online response rates and times: Background and guidance for industry' Ipathia Inc., [Online] available: http://www.supersurvey.com/papers/supersurvey_white_paper_res ponse_rates.pdf (accessed 10 May 2012).

Hampton, A., Cooper, S. \& McGowan, M. 2009. 'Female entrepreneurial networks and networking activity in technologybased ventures: An exploratory study', International Small Business Journal, 27(2): 193-214.

Herrington, M., Kew, J. \& Kew, P. 2014. 2014 GEM South Africa report: South Africa: The crossroads - a goldmine or a time bomb? Global Entrepreneurship Monitor, University of Cape Town DUNE Unit, Cape Town, South Africa.

Hughes, K.D. \& Jennings, J.E. 2012. Global women's entrepreneurship research: diverse settings, questions and approaches, Edward Elgar, Cheltenham/Northampton, U.K.

Hughes, K.D., Jennings, J.E. Brush, C., Carter, S. \& Welter, F. 2012. 'Extending women's entrepreneurship research in new directions', Entrepreneurship Theory and Practice, 36(3): 429-442.

Jayawarna, D., Rouse, J. \& Kitching, J. 2013. 'Entrepreneur motivations and life course', International Small Business Journal, 31(1): 34-56.

Klyver, K. \& Terjesen, S. 2007. 'Entrepreneurial network composition: An analysis across venture development stage and gender', Women in Management Review, 22(8): 682-688.

Kollmann, T., Kuckertz, A. \& Stäckmann, C. 2009. 'Continuous innovation in entrepreneurial growth companies: Exploring the ambidextrous strategy', Journal of Enterprising Culture, 17(3): 297322.

Kuckertz. A., Kohtamäki. M. \& Droege, C. 2010. 'The fast eat the slow: The impact of strategy and innovation timing on the success of technology-oriented ventures', International Journal of Technology Management, 52(1-2): 175-188.

Levinson, D.J., Darrow, C.N., Klein, E.B., Levinson, M.H. \& McKee, B. 1978. The Seasons of a Man's Life, Random House LLC, New York.

Levinthal, D. \& March, J. 1993. 'The myopia of learning', Strategic Management Journal, 13(14): 95-112.

Lewis, K., Harris, C., Morrison, R., Ho, M., Jawahar, I.M. \& Al Ariss, A. 2015. 'The entrepreneurship motherhood nexus: A longitudinal investigation from a boundary-less career perspective', Career Development International, 20(1): 21-37.

Lubatkin, M.H., Simsek, Z., Ling Y. \& Veiga, J.F. 2006. 'Ambidexterity and performance in small-to medium-sized firms:
The pivotal role of top management team behavioral integration', Journal of Management, 32(5): 646-672.

Mangaliso, M.P. 2001. 'Building competitive advantage from Ubuntu: Management lessons from South Africa', The Academy of Management Executive, 15(3): 23-33.

Mäntylä, T. 2013. 'Gender differences in multitasking reflect spatial ability’, Psychological Science, 24: 514-520.

March, J.G. 1991. 'Exploration and exploitation in organizational learning', Organization Science, 2(1): 71-87.

Marlow, S. Henry, C. \& Carter, S. 2009. 'Exploring the impact of gender upon women's business ownership: Introduction', International Small Business Journal, 27(2): 139-148.

Martins, L.L., Eddleston, K.A. \& Veiga, J.F. 2002. 'Moderators of the relationship between work-family conflict and career satisfaction', Academy of Management Journal, 45(2): 399-409.

McGrath, R.G. 2001. 'Exploratory learning, innovative capacity and managerial oversight', Academy of Management Journal, 44(1): 118-131.

Mitchell, R.K., Mitchell, B.T. \& Mitchell, J.R. 2009. Entrepreneurial scripts and entrepreneurial expertise: The information processing perspective, in Carsud, A. L. and Brannback (Eds.), Understanding the Entrepreneurial Mind, Springer, New York: 97-137.

Mitchell, J.R. \& Shepherd, D.A. 2010. 'To thine own self be true: Images of self, images of opportunity, and entrepreneurial action', Journal of Business Venturing, 25(1): 138-154.

Morris, M.H., Miyasaki, N.N., Watters, C.E. \& Coombes, S.M. 2006. 'The dilemma of growth: Understanding venture size choices of women entrepreneurs', Journal of Small Business Management, 44(2): 221-244.

Nunnally, J.C. 1978. Psychometric Theory, McGraw-Hill, New York, NY.

Pashler, H. 2000. 'Task switching and multitask performance', in Monsell, S. and Driver, J. (Eds.), Attention and Performance XVIII: Control of Mental Processes, MIT Press, Cambridge, MA.

Patterson, N. \& Mavin, S. 2009. 'Women entrepreneurs jumping the corporate ship and gaining new wings', International Small Business Journal, 27(2): 173-192.

Pease, A. \& Pease, B. 2003. Why Men Can Only Do One Thing at a Time And Women Never Stop Talking, Orion, Bhopal, India.

Podsakoff, P.M., MacKenzie, S.B., Lee, J. \& Podsakoff, N.P. 2003. 'Common method biases in behavioral research: A critical review of the literature and recommended remedies', Journal of Applied Psychology, 88(5): 879-903.

Priola, V. 2004. 'Gender and feminine identities: Women as managers in a UK academic institution', Women in Management Review, 19(8): 421-430.

Raisch, S., Birkinshaw, J., Probst, G. \& Tushman, M.L. 2009. 'Organizational ambidexterity: Balancing exploitation and 
exploration for sustained performance', Organization Science, 20(4): 685-695.

Sarasvathy, S.D. 2001. 'Causation and effectuation: Toward a theoretical shift from economic inevitability to entrepreneurial contingency', Academy of Management Review, 26(2): 243-263.

Sarasvathy, S. D. 2008. Effectuation: Elements of entrepreneurial expertise, Edward Elgar, Cheltenham.

Savickas, M.L. 2002. Career construction: A developmental theory of vocational behaviour, in Brown, D. \& Associates (Eds.), Career Choice and Development (4th ed.), Jossey-Bass, San Francisco, CA,: 149-205.

Simo Kengne, B.D. 2016. 'Mixed-gender ownership and financial performance of SMEs in South Africa: A multidisciplinary analysis', International Journal of Gender and Entrepreneurship, 8(2): 117-136.

Smith, W.K. \& Tushman, M.L. 2005. 'Managing strategic contradictions: A top management model for managing innovation streams', Organization Science, 16(5): 522-536.

Sorenson, R.L., Folker, C.A. \& Brigham, K.H. 2008. 'The collaborative network orientation: Achieving business success through collaborative relationships', Entrepreneurship Theory and Practice, 32(4): 615-634.

Spivak, G.C. 1987. In other worlds: Essays in cultural politics, Taylor and Francis, London, UK.

Statistics South Africa. 2012. Census 2011, [Online] available: http://www.statssa.gov.za/publications/P03014/P030142011.pdf.

Stoet, G., O'Connor, D.B., Conner, M. \& Laws, K.R. 2013. 'Are women better than men at multi-tasking?', BMC Psychology, 1(18): $1-10$.

Stroh, L.K. \& Reilly, A.H. 1999. Gender and careers: Present experiences and emerging trends, in Powell, G. N. (Ed.), Handbook of Gender and Work, Sage, Thousand Oaks, CA, Publications: 307324.

Super, D. 1990. A life span approach to career development, in Brown, D. and Brooks, L. (Eds.), Career Choice and Development: Applying Contemporary Theories to Practice, Jossey-Bass, San Francisco, CA:145-196.

Terrell, K. \& Troilo, M. 2010. 'Values and female entrepreneurship', International Journal of Gender and Entrepreneurship, 2(3): 260-286.

Turner, N., Swart, J. \& Maylor, H. 2013. 'Mechanisms for managing ambidexterity: A review and research agenda', International Journal of Management Reviews, 15(3): 317-332.

Urban, B. 2006. 'Entrepreneurship in the rainbow nation: Effect of cultural values and ESE on intentions', Journal of Developmental Entrepreneurship, 11(03): 171-186.

Valchev, V.H., Nel, J.A., Van de Vijver, F.J., Meiring, D., De Bruin, G.P. \& Rothmann, S. 2013. 'Similarities and differences in implicit personality concepts across Ethnocultural groups in South Africa', Journal of Cross-Cultural Psychology, 44(3): 365-388.
Verheul, I., Uhlaner, L. \& Thurik, R. 2005. 'Business accomplishments, gender and entrepreneurial self-image', Journal of Business Venturing, 20(4): 483-518.

Vogt, L. \& Laher, S. 2009. 'The five factor model of personality and individualism/collectivism in South Africa: An exploratory study', Psychology in Society, 37: 39-54.

Volery, T., Mueller, S. and \& Siemens, B. 2015. 'Entrepreneur ambidexterity: A study of entrepreneur behaviours and competencies in growth-oriented small and medium-sized enterprises', International Small Business Journal, 33(2): 109-129.

Walrave B, van Oorschot K.E. \& Romme A.G.L. 2011. 'Getting trapped in the suppression of exploration: A simulation model', Journal of Management Studies, 48(8): 1727-1751.

Walter, A., Auer, M. \& Ritter, T. 2006. 'The impact of networking capabilities and entrepreneurial orientation on university spin-off performance', Journal of Business Venturing, 21(4): 541-567.

Westerberg, M., Singh, J. \& Hackner, E. 1997. 'Does the CEO matter? An empirical study of small Swedish firms operating in turbulent environments', Scandinavian Journal of Management, 13(3): 251-270.

Westerberg, M. \& Wincent, J. 2008. Networking capability and entrepreneurship: Refinement of a scale and test of a framework, in AGSE-Babson Regional Entrepreneurship Research Exchange in Melbourne, Australia, 2008.

Wilson, F., Kickul, J. \& Marlino, D. 2007. 'Gender, entrepreneurial self-efficacy, and entrepreneurial career intentions: Implications for entrepreneurship education', Entrepreneurship Theory and Practice, 31(3): 387-406.

Wiltbank, R., Dew. N., Read, S. \& Sarasvathy S.D. 2006. 'What to do next? The case for non-predictive strategy', Strategic Management Journal, 27(10): 981-998.

Wiltbank, R., Read, S., Dew, N. \& Sarasvathy, S.D. 2009. 'Prediction and control under uncertainty: Outcomes in angel investing', Journal of Business Venturing, 24(2): 116-133.

Wood, R.E. \& Bandura, A. 1989. 'Social cognitive theory of organizational management', Academy of Management Review, 14: 361-384.

Wu, C. 2013. 'Gender as a category of analysis: Reconciling feminist theory with feminist methodology', Graduate Journal of Social Science, 10(3): 38-53.

Yousafzai, S.Y., Saeed, S. \& Muffatto, M. 2015. 'Institutional theory and contextual embeddedness of women's entrepreneurial leadership: Evidence from 92 countries', Journal of Small Business Management, 53(3): 587-604. 


\section{Appendix I: Questionnaire items used for analysis in this study}

Questions were related to a Project X chosen, which were classified in one of four categories: a new marketing or business initiative; a new project or process innovation; a human resource initiative; and a new venture.

\begin{tabular}{|c|c|}
\hline Constructs & Items \\
\hline \multicolumn{2}{|c|}{ Ambidexterity - Causation (exploitation) } \\
\hline & $\begin{array}{l}\text { I selected the long-run opportunity that I } \\
\text { thought would provide the best returns. } \\
\text { I considered different business models for } \\
\text { my initiative (project/venture). } \\
\text { I planned business strategies, before taking } \\
\text { action. } \\
\text { I implemented control processes to make } \\
\text { sure objectives were met. } \\
\text { I had a clear vision of where I wanted to end } \\
\text { up. }\end{array}$ \\
\hline \multicolumn{2}{|c|}{ Ambidexterity - Effectuation (exploration) } \\
\hline Affordable loss & $\begin{array}{l}\text { I was careful not to risk more money than I } \\
\text { am willing to lose with the initial idea. } \\
\text { I was careful not to commit more resources } \\
\text { than I could afford to lose. }\end{array}$ \\
\hline Flexibility & $\begin{array}{l}\text { I adapted what I was doing to the resources } \\
\text { available for the project. } \\
\text { I developed a strategy to best take advantage } \\
\text { of resources and capabilities. }\end{array}$ \\
\hline $\begin{array}{l}\text { Pre- } \\
\text { commitments }\end{array}$ & $\begin{array}{l}\text { I reduced the amount of uncertainty by using } \\
\text { a substantial number of agreements with } \\
\text { customers, suppliers and other } \\
\text { organisations. } \\
\text { I made use of agreements with business } \\
\text { partners to reduce uncertainty. }\end{array}$ \\
\hline \multicolumn{2}{|c|}{ Dependent variables } \\
\hline $\begin{array}{l}\text { Entrepreneurial } \\
\text { self-efficacy } \\
(\text { ESE) }\end{array}$ & $\begin{array}{l}\text { I am able to achieve most of the goals that I } \\
\text { have set for myself. } \\
\text { When facing difficult tasks, I am certain that } \\
\text { I will accomplish them. } \\
\text { In general, I think that I can obtain outcomes } \\
\text { that are important to me. } \\
\text { I believe I can succeed at most any } \\
\text { endeavour to which I set my mind. } \\
\text { I am confident that I can perform effectively } \\
\text { on many different tasks. }\end{array}$ \\
\hline $\begin{array}{l}\text { Relationship } \\
\text { skills }\end{array}$ & $\begin{array}{l}\text { I have the ability to build good personal } \\
\text { relationships with my business partners. } \\
\text { Managers and employees often give } \\
\text { feedback to each other regarding new } \\
\text { business initiatives. } \\
\text { I analyse what I would like to achieve with } \\
\text { each partner. } \\
\text { I have regular meetings with all stakeholders } \\
\text { for every project. } \\
\text { I almost always solve problems } \\
\text { constructively with my partners. } \\
\text { I can deal flexibly with my partners. } \\
\text { I am aware of the target markets my partners } \\
\text { operate in. }\end{array}$ \\
\hline
\end{tabular}

